\title{
COVID-19: Are Malaysians embracing or suffering the new normality?
}

\author{
Dinyadarshini Johnson ${ }^{1}$, Stanley Eng Chee Ren ${ }^{2}$, Hema Darshinee Johnson ${ }^{3}$, Vengadesh Letchumanan ${ }^{1 *}$ \\ ${ }^{1}$ Novel Bacteria and Drug Discovery Research Group (NBDD), Microbiome and Bioresource Research Strength (MBRS), \\ Jeffrey Cheah School of Medicine and Health Sciences, Monash University Malaysia, 47500 Bandar Sunway, Selangor \\ Darul Ehsan, Malaysia \\ ${ }^{2}$ Hospital Sultan Ismail, Jalan Mutiara Emas Utama, Taman Mount Austin, 81100 Johor Bahru, Johor, Malaysia \\ ${ }^{3}$ Hospital Selayang, B21, Lebuhraya Selayang - Kepong, 68100 Batu Caves, Selangor, Malaysia
}

\begin{abstract}
The COVID-19 pandemic has inevitably rendered a paradigm shift in peoples' day-to-day normality. The pandemic has precipitated various reaction and responses from people across the globe especially with the enforcement of preventive measures initiated by their respective government forces. The movement control order (MCO) was one of the drastic measures taken in Malaysia adhering to the guideline released by World Health Organization (WHO) and has been made effective since $18^{\text {th }}$ of March 2020. The execution of MCO in a developing setting like Malaysia certainly impacts its people on several fronts, especially those from low-socioeconomic background. It creates a domino effect from an economical to psychological aspects at both societal and individual levels. Subsequently, a conditional MCO (CMCO) has been introduced during midway through Phase 4 of MCO with eased restrictions, particularly considering economic downturn. CMCO is followed by recovery MCO (RMCO) phase. In this article, we aim to share some insights while highlighting the impacts of COVID-19 with an emphasize on the psychosocial aspect, particularly during MCO phases, which has thus imposed a new normality on Malaysians.
\end{abstract}

Keywords: COVID-19; Malaysia; movement control order (MCO); impacts; new normality

Received: $1^{\text {st }}$ August 2020

Accepted: $20^{\text {th }}$ August 2020

Published Online: $31^{\text {st }}$ August 2020
*Correspondence: Vengadesh Letchumanan, Novel Bacteria and Drug Discovery Research Group (NBDD), Microbiome and Bioresource Research Strength (MBRS), Jeffrey Cheah School of Medicine and Health Sciences, Monash University Malaysia; vengadesh.letchumanan1@monash.edu.

Citation: Johnson D, Ren SEC, Johnson HD et al. COVID-19: Are Malaysians embracing or suffering the new normality? Prog Microbes Mol Biol 2020; 3(1): a0000102. https://doi.org/10.3687/pmmb. a0000102

\section{Introduction}

A coronavirus disease, known as COVID-19, is a deadly manifestation of a novel virus which came to light in December 2019 when pneumonia of unknown cause was first reported in China ${ }^{[1-4]}$. The outbreak took a downward spiral when World Health Organization (WHO) subsequently declared it as a pandemic in early March 2020 with death approaching nearly 1000 in the European Region $^{[5,6]}$. To date, a whopping total of approximately 770, 000 deaths and close to 22 million confirmed cases of COVID-19 have been reported globally ${ }^{[7]}$. Amongst Southeast Asia countries, Malaysia records one of the highest numbers of confirmed cases with over 6000 cases and 103 total deaths by early May 2020, however this scenario gradually changed as the vigorous measures taken by the authorities through MCO managed to reasonably arrest the rapid spread of Covid-19 infection in local setting. Since June 2020 until the present, the reported number of new cases remains within 2 digits which inevitably reflects the effective countermeasures executed by the local authorities ${ }^{[8,9]}$.

As part of the federal government's initiative to combat the rapid spread of COVID-19 with an alarming surge in new cases amounting to 190 cases on $15^{\text {th }}$ of March 2020, a movement control order (MCO) has been issued effective from $18^{\text {th }}$ of March 2020 till $12^{\text {th }}$ of May $2020^{[10]}$. The initial order for a period of 2 weeks has been gradually extended to a total period of 8 weeks, adhering to the WHO's guideline ${ }^{[8,11]}$. Each phase of $\mathrm{MCO}$, lasting for 2 weeks respectively, sees a gradual modification on the restriction rules, depending on the reported number of new cases and recovery rate. The strictest rules were observed during phase 2 and phase 3 of MCO starting from $1^{\text {st }}$ of April 2020 till $28^{\text {th }}$ of April 2020. During these phases, travel distance was limited to within $10 \mathrm{~km}$ of radius from home, only one representative from each family allowed to travel at a time to buy essentials, and business hours and delivery 
time were limited to $8 \mathrm{am}$ till $8 \mathrm{pm}$. There were some areas in major cities subjected to complete lockdown as well. Almost no tolerance was given to $\mathrm{MCO}$ violators where 9090 offenders were arrested while 4036 compounds were issued as of $13^{\text {th }}$ of April 2020 ${ }^{[12,13]}$. As soon after implementation of $\mathrm{MCO}$, the number of new cases peaked at most 235 cases per day in March end with a more vigorous screening process taking place across the nation. The trend has been generally decreasing since then, however, with some fluctuations in number of new cases reported on a daily basis. The recovery rate has been reported as high as $70 \%{ }^{[8]}$. During midway through phase 4, from $29^{\text {th }}$ of April 2020 till $12^{\text {th }}$ of May 2020, a conditional MCO has been introduced as Phase 5 starting from $4^{\text {th }}$ of May 2020 by easing some of the restrictions mainly catering to reopening of selected economic sectors involving essential services and manufacturing of critical products. The psychosocial well-being of general public has also been considered by allowing two family members to travel in a car, beyond $10 \mathrm{~km}$ of radius from home for health needs, groceries and food, and some outdoor sports activities were also allowed while strictly exercising social distance and self-hygiene ${ }^{[11,14-16]}$.

Challenges and difficulties inevitably accompany the execution of this obligatory mandate at numerous aspects as far as the public is concerned. However, the same amusingly unfolds some fundamental values which hold the society together amid an unfathomable crisis. This article intends to explore some insights and impacts relating to the COVID-19 situation in Malaysia from a societal perspective during the MCO phases particularly.

\section{Measure of societal awareness and readiness}

The announcement of MCO has inevitably provoked an alarming sense of fear and insecurity amongst the public, however, at varying concerns amongst the different strata within the society, largely influenced by individual socioeconomic status. Panic-buying is one of the resulting occurrences which happened at early phase of MCO where people flocked to the supermarkets, grocery stores and pharmacies, especially in major cities to stock up on provisions for their homes ${ }^{[17]}$. Essentials were absurdly purchased in larger than usual amount with sole aim to survive the foreseen restriction due to MCO. This is probably an immediate but fading gratification considering the mismatch between the needs and the wants in a long run and poorly understood terms of MCO.

The wearing of face mask is another aspect which becomes a highly critical measure of societal awareness and knowledge. Mask has become one of the most sought-after essentials during this phase. While the usage of mask becomes a matter of debate, it has been made compulsory to wear a face mask upon entering any outside premises currently. Although this was not one of the mandates by the government at the initial stage, starting from $1^{\text {st }}$ of August 2020, it has been made compulsory for everyone to wear mask in public domains $^{[18,19]}$. Given the asymptomatic yet possibly contagious phase of COVID-19 incubation period, the wearing of mask is merely recommended for everyone being outside ${ }^{[20,21]}$. However, the paranoia of wearing a mask to the extent of making own masks from random cloths or even tissue paper, and stealing masks from hospitals while neglecting other preventive measures only point to the lack of comprehensive understanding on the rationale behind proper usage of personal protective equipment (PPE) amongst the public ${ }^{[22-24]}$.

While panic-buying and face mask obsession became the highlight during the initial phases of $\mathrm{MCO}$, the announcement of conditional MCO with eased restrictions triggered an unexpected response from 130, 000 over Malaysians who signed a petition to call it off and continue with the existing MCO rules. A fear of repeating mistakes of other countries by easing restrictions only to see another wave of COVID-19 has provoked such a response amongst the public ${ }^{[18]}$. Resonating with the public's fear, an increased number of new cases was seen during phase 4 after easing some movement restriction, with 94 cases reported on $29^{\text {th }}$ of April 2020, followed by another peak at 105 cases on $2^{\text {nd }}$ of May $2020^{[8]}$.

\section{Chain of impacts and remedies from a societal perspective}

The MCO period has created a new normality for the entire nation at a liability yet to be fully apprehended. The new normality in Malaysian context became apparent with the enforcement of $\mathrm{MCO}$ when strictest restrictions were introduced during critical phase 2 and phase 3 . The glaring impacts from economical and psychosocial fronts remain a huge concern given the prolonged period of MCO with uncertainties regarding its further extension.

A recent survey conducted by The Department of Statistics, Malaysia, participated by 168,182 respondents aged 15 years and above, revealed that almost $50 \%$ of the selfemployed workers have lost their job while $94.8 \%$ reported reduced monthly income. It further revealed that more than $50 \%$ of the working community is not financially prepared for a total lockdown ${ }^{[25]}$. Another group detrimentally affected by the restriction is the daily wage workers, more so those with families to support due to complete loss of income ${ }^{[26]}$. Malaysians residing in the southern-most state of Johor who travel across the causeway for work in Singapore were also impacted by the MCO issued by both the countries. Some barely had enough savings to support their prolonged stay in Singapore while some were asked to go on an unpaid leave $\mathrm{e}^{[27]}$.

The psychosocial effect resulting from the restrictions imposed via MCO differ from one stratum of the community to another to some large extent. These differences are probably attributable to the differences in economic capacity of a stratum. For an instance, panic-buying, is probably an incongruent description of the economically disadvantaged stratum of the society for buying capacity becomes a disheartening matter of concern. People who have been charged for violation of MCO include joggers and golfers at one end of the spectrum and fishermen who were in dire need to feed their families at another ${ }^{[26,28,29]}$. The markedly differing concerns and priorities divide the psychosocial effects within the different strata of community. Paradoxically, the virus does not have the capacity to be selective of its sufferer, thus a social dilemma 
arises when it comes to the execution of the general order like MCO in a developing setting.

Befrienders, a non-profit organization which provides a $24 / 7$ helpline for emotional support, reported an increase of $13 \%$ of calls during the initial phase of MCO with $9 \%$ expressing concerns and anxiety due to COVID-19 and $\mathrm{MCO}^{[28]}$. 'Talian Kasih', a 24/7 helpline by government body dedicated to providing support related to welfare and community, reported a $57 \%$ of rise in number of calls during MCO. Concerns were expressed regarding an increase in domestic violence cases and further predicts a possible rise in child abuse and incest during $\mathrm{MCO}^{[30]}$.

Loss of job and income without a financial backup while being confined in a space with families to support would impact the psychological well-being of any affected individual even for a short period. On the other hand, those who have the privilege of continuing work from home requires a minimum of well-equipped networking facilities and an ideal environment free from distractions. This becomes a challenge in a rural setting, particularly in some parts of East Malaysia, where there is no internet viability or basic amenities to support work-from-home alternative which depends on internet ${ }^{[31]}$. Individuals who are committed to families, especially with younger children or family members who need extra care and attention, equally have to juggle between work and family, especially when interrupted.

The closing of academic institutions and postponement of major public exams become another form of distress to parents, educators and students themselves. Online and home-based learning has been highly encouraged and advocated, however, students from rural background with no access to internet and proper coaching would undoubtedly jeopardize students' academic performance in a long run ${ }^{[32-34]}$. It would be an unrealistic expectation to have all the school children remain motivated to study throughout the MCO period. Boredom, agitation and stress could not only affect the children, but also the parents or caregivers who equally have the responsibility to ensure an adequate and healthy home environment for their children.

From another perspective, in a common ground of psychosocial effects, the most difficult situation comes when one has to grapple with the loss of their loved ones, be it due to COVID-19 or other causes. It becomes a painful bid-adieu to these souls for the sorrowful memory it creates ${ }^{[35]}$. There were people arrested and fined for attending funeral of loved ones during MCO which makes the grieving even more painful ${ }^{[36]}$. Perhaps no remedy is capable of recovering one from the loss of loved ones in such circumstances.

As remedial measures tackling financial aspect, Malaysians were given financial aid through the 'PRIHATIN Economic Stimulus Package' where a one-off amount was credited into accounts of eligible applicants based on net monthly household income of no more than MYR 8000. The 'B40 group', with net monthly household income of less than MYR 4000 for married individuals and less than MYR 2000 for singles, was eligible for the highest aid fund of MYR 1600 and MYR 800 respectively ${ }^{[37]}$. Other funding aids, including deferment of loan payment up to six months and $15-50 \%$ discount on electricity bills do provide a temporary relief ${ }^{[38]}$. The temporary diversion due to MCO may possibly mask the actual extent of economic burden imposed on both individuals and nation. Nevertheless, it certainly signals a forewarning on a long term and lasting detrimental consequences considering a recent estimate of Malaysian Ringgit (MYR) of 2.4 billion loss per day owing to economic shutdown during $\mathrm{MCO}^{[39]}$.

In the face of countless issues and concerns, the forthcoming of several non-governmental organizations (NGOs) and individuals to reach out to the needy including the homeless and refugees is commendable. Free food distribution, shelter to the homeless and fund-raising via social media are all some of the noteworthy deeds ${ }^{[40]}$. The nation's frontline healthcare workers could not have become more visible for their unremitting labor in fighting COVID-19. The public took it to social media to express their unwavering gratitude for all these selfless heroes while ceaselessly reminding one another to stay home and obey the MCO rules ${ }^{[41]}$. Enduring eternal claustrophobic hours in PPE suit, heavily drenched in sweat, heading home with exhaustion and fear of possibly carrying and passing on the infection to their loved ones only to call it a day could not be described as nothing but a precious call to perform their clinical duties in this most needed time of crisis. The fellow countrymen are probably more aware than ever the value of a timeless noble service like this and that it deserves far a greater recognition and salutation in days to come.

The four phases of MCO were probably the strictest and tightest lockdown period Malaysians have had endured to date. Following $\mathrm{MCO}, \mathrm{CMCO}$ was introduced in Phase 5 till $9^{\text {th }}$ of June and subsequently recovery MCO (RMCO) up to $31^{\text {st }}$ of August 2020 $0^{[42]}$. Restrictions were eased and economic sectors were gradually allowed to operate at staged phases. Standard operating procedure (SOP) was administered across all the operating business outlets. A mobile app known as 'MySejahtera' has been introduced by the Ministry of Health (MOH) Malaysia as a mean to monitor Covid-19 outbreak. This app provides its user with an updated information on Covid-19 status in Malaysia and health screening facilities, individual risk status and QR code reader to enable individual check-in at each visit to various locations. This app channels the information to the $\mathrm{MOH}$, thus paves the way for effective countermeasures which marks the importance of digital health application in the midst of public health crisis ${ }^{[43]}$. As of $15^{\text {th }}$ of August 2020, Malaysia has recorded a total number of 9175 positive cases with $96.25 \%$ or 8831 cases of discharges, and $1.36 \%$ or 125 number of total deaths (Figure 1). Since late May, not long after $\mathrm{CMCO}$ was introduced, the number of active cases based on daily record has remained within 2 digits and this marks the successful execution of Covid-19 measures in Malaysian setting ${ }^{[44]}$. Heavy penalties will be imposed on individuals who disobey the set SOPs, including a fine not exceeding RM1000 or imprisonment up to six months ${ }^{[16]}$. Although the battle to combat Covid-19 is still ongoing, Malaysians continue to hope for brighter days ahead while recognizing the applaudable measures taken by the respective authorities. 


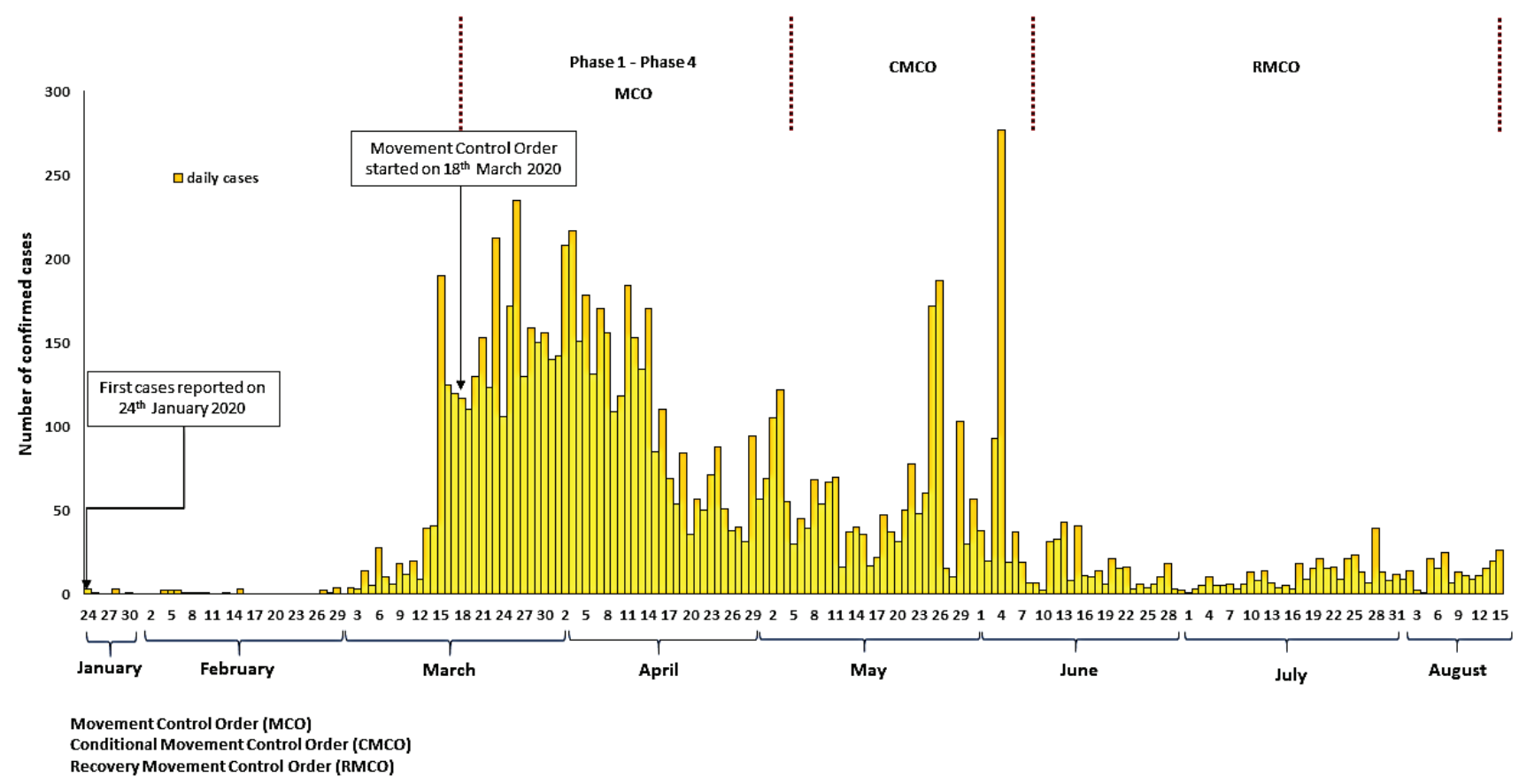

Figure 1. The daily confirmed COVID-19 cases reported in Malaysia up to 15 August 2020 based on Ministry of Health Malaysia. The movement control order (MCO) was implemented on 18 March 2020 in four phases followed by conditional movement control order (CMCO). Malaysian were restricted under recovery movement control order from 10 June 2020-31 August 2020.

\section{Conclusion}

The gigantic wave of COVID-19 has awakened the entire nation and calls for a bigger reformation in days to come at both individual and national fronts. Economic downturn becomes a huge concern especially in developing countries like Malaysia. Psychosocial effect is influenced by economic capacity of an individual to a great extent; however, it becomes a borderless effect when emotional sufferings and trauma are considered. Despite various limitations and concerns given the poorly anticipated circumstances, a responsible member of the nation should remain focused on working hand in hand to eradicate the egregious conquest of an invisible creature. The rapid spread of COVID-19 leaves no space for any excuse to violate the governmental mandates. The miserable and dampening economical and psychosocial repercussions of COVID-19 could only be revived by a robust and healthy citizen who survive this phase with deepest sense of conscience and responsibility. Every individual would shoulder even a greater responsibility in curbing the pandemic as well as recovering from personal losses after cessation of MCO. A continuous spread of awareness and reminders are necessary to ensure strict compliance to preventive measures. Technology can never be more accommodating than now to keep the momentum going. All said, let this phase not be taken for granted, for a profound sense of humility has been awakened in the face a natural calamity.

\section{Conflict of Interest}

The authors declare that the research was conducted in the absence of any commercial or financial relationships that could be construed as a potential conflict of interest.

\section{Author Contributions}

The literature search and data collection were performed by DJ. The manuscript was written by DJ. Technical supports and proofreading were contributed by SC-HE, HDJ and VL. VL set up the research project.

\section{Funding}

This work was supported by SEED Funding from Microbiome and Bioresources Research Strength (MBRS), Jeffrey Cheah School of Medicine and Health Sciences (JCSMHS) (Vote Number: MBRS/JCSMHS/01/2020).

\section{Acknowledgement}

Authors would like to acknowledge the support and guidance from Professor Shajahan Yasin, Head of School, Jeffrey Cheah School of Medicine and Health Sciences (JCSMHS), Monash University Malaysia that enabled the success of this project. 


\section{Reference}

1. World Health Organization. Novel Coronavirus 2019. [Cited 2020 April 14]. Available from: https://www.who.int/timorleste/emergencies/ novel-coronavirus-2019.

2. Ser H-L, Letchumanan V, Law JW-F, et al. PMMB COVID-19 Bulletin: Spain. Prog. Microb. Mol. Biol. 2020; 3(1).

3. Letchumanan $\mathrm{V}, \mathrm{Ab}$ Mutalib N-S, Goh B-H, et al. Novel coronavirus 2019-nCoV: Could this virus become a possible global pandemic. Prog. Microb. Mol. Biol. 2020; 3(1)

4. Lee VS, Chong WL, Sukumaran SD, et al. Computational screening and identifying binding interaction of anti-viral and anti-malarial drugs: Toward the potential cure for SARS-CoV-2. Prog. Drug Dis. Biomed. Sci. 2020; 3(1).

5. World Health Organization. WHO announces COVID-19 outbreak. 2020. [Cited 2020 April 14]. Available from: http://www.euro.who. int/en/health-topics/health-emergencies/coronavirus-covid-19/news/ news/2020/3/who-announces-covid-19-outbreak-a-pandemic.

6. Tan LT-H, Letchumanan V, Ser H-L, et al. PMMB COVID-19 Bulletin: United Kingdom. Prog. Microb. Mol. Biol. 2020; 3(1).

7. Coronavirus Update (Live): 3,498,151 Cases and 244,988 Deaths from COVID-19 Virus Pandemic. Worldometer [Internet]. 2020. [Cited 2020 May 2]. Available from: https://www.worldometers.info/coronavirus/. Department of Statistics Malaysia. UKK DOSM [Internet]. 2020. [Cited 2020 May 2]. Available from: https://ukkdosm.github.io/ covid-19.

9. World Health Organization. Coronavirus disease (COVID-19) Pandemic. [Cited 2020 April 14]. Available from: https://www.who. int/emergencies/diseases/novel-coronavirus-2019.

10. Ser H-L, Tan LT-H, Law JW-F, et al. Genomic analysis of severe acute respiratory syndrome coronavirus 2 (SARS-CoV-2) strains isolated in Malaysia. Prog. Microb. Mol. Biol. 2020; 3(1).

11. Prime Minister's Office of Malaysia. Perutusan Khas Perdana Menteri (2020 April 23) [Cited 2020 April 26]. Available from: https://www. pmo.gov.my/2020/04/teks-perutusan-khas-perdana-menteri-23. april-2020/

12. Zainuddin A. Stricter measures under MCO Phase 3. The Malaysian Reserve [Internet]. 2020 April 15 [Cited 2020 May 2]. Available from: https://themalaysianreserve.com/2020/04/15/stricter-measures-undermco-phase-3/.

13. Matdura S. 5 new updates Malaysians must take note during Phase 2 of the MCO. Ask Legal [Internet]. 2020 April 5 [Cited 2020 May 2]. Available from: https://asklegal.my/p/5-new-updates-malaysianmovement-control-order-covid.

14. Zainul E. MCO easing to start with economic sectors-Health DG [Internet]. The Edge Markets; 2020 [Updated 2020 April 29; cited 2020 May 2]. Available from: http://www.theedgemarkets.com/article/mcoeasing-start-economic-sectors--health-dg.

15. One can now travel beyond $10 \mathrm{~km}$ for food, groceries and medical needs under MCO Phase 4. The Star [newspaper on the Internet]. 2020 April 29 [Cited 2020 May 2]. Available from: https://www.thestar.com. my/news/nation/2020/04/29/one-can-now-travel-beyond-10km-foressential-shopping-medical-needs-under-mco-phase-4

16. Lim I. Minister: Malaysia now in Phase Five, Putrajaya's new rules fo CMCO applies nationwide. Malay Mail [newspaper on the Internet]. 2020 May 4. [Cited 2020 August 16]. Available from: https://www. malaymail.com/news/malaysia/2020/05/04/minister-malaysia-now-inphase-five-putrajayas-new-rules-for-cmco-applies-n/1862924.

17. Department of Statistics Malaysia. UKK DOSM [Internet]. 2020. [Cited 2020 April 15]. Available from: https://ukkdosm.github.io/.

18. Annuar A. Face masks not mandatory, people shouldn't be arrested for not wearing one, says Ismail Sabri. Malaymail [newspaper on the Internet]. 2020 April 17 [Cited 2020 May 2]. Available: https:/ www.malaymail.com/news/malaysia/2020/04/17/face-masksnot-mandatory-people-shouldnt-be-arrested-for-not-wearing-one$\mathrm{sa} / 1857645$.

19. Zolkepli F. Face mask compulsory from Aug 1. The Star [newspaper on the Internet]. 2020 July 24 [Cited 2020 August 16]. Available from: https://www.thestar.com.my/news/nation/2020/07/24/face-maskcompulsory-from-aug-1.

20. World Health Organization (WHO). Advice on the use of masks in the context of COVID-19: interim guidance. World Health Organization [cited 2020 April 6].

21. Kaos Jr J and Rahim R. Health DG: Wear mask and practise social distancing. The Star [newspaper on the Internet]. 2020 April 15 [Cited 2020 May 3]. Available from: https://www.thestar.com.my/ news/nation/2020/04/15/health-dg-wear-mask-and-practise-socialdistancing.

22. Yeoh A. Covid-19: Doctors urge Malaysians not to steal hand sanitisers from hospitals. The Star [newspaper on the Internet]. 2020 Mar 21 [Cited 2020 May 2]. Available from: https://www.thestar.com.my/ tech/2020/03/20/covid-19-doctors-urge-malaysians-not-to-steal-handsanitisers-from-hospitals

23. Zainal S. Malaysians make own face masks. The Star [newspaper on the Internet]. 2020 April 7 [Cited 2020 May 2]. Available from: https:/ www.thestar.com.my/news/nation/2020/04/07/malaysians-make-ownface-masks.

24. Bernama. Seventh day of MCO to focus on social distancing at public markets, supermarkets. Astro Awani [Internet]. 2020 March 24 [Cited
2020 April 20]. Available from: http://english.astroawani.com/malaysianews/seventh-day-mco-focus-social-distancing-public-marketssupermarkets-234978.

25. Report of special survey on effects of COVID-19 on economy \& individual (Round 1). Department of Statistics Malaysia [Internet] 2020 [Cited 2020 April 20]. Available from: https://www.dosm. gov.my/v1/index.php? $\mathrm{r}=$ column/cone \& menu id=a0dyT2d5 UmFMNEZJVTlmL0k5cFJNZz09.

26. Aqilah I. MCO violation: Golfers jailed three days, fined RM1,000 each after pleading guilty. The Star [newspaper on the Internet]. 2020 April 17 [Cited 2020 May 2]. Available from: https://www.thestar.com.my/ news/nation/2020/04/17/mco-violation-golfers-jailed-three-days-finedrm1000-each-after-pleading-guilty.

27. Loke L. Covid-19: Told to go on unpaid leave, Malaysians in Singapore find themselves in limbo. Today [newspaper on the Internet]. 2020 April 19 [Cited 2020 May 2]. Available from: https://www.todayonline.com singapore/covid-19-told-go-unpaid-leave-malaysians-singapore-findthemselves-limbo.

28. Look after mental health during MCO. The Star [newspaper on the Internet]. 2020 April 14 [Cited 2020 May 2]. Available from: https:// www.thestar.com.my /opinion/letters/2020/04/14/look-after-mentalhealth-during-mco.

29. Kaur M. Duo caught fishing say they were only trying feed their families; both get three months' jail. The Star [newspaper on the Internet]. 2020 April 4 [Cited 2020 May 2]. Available from: https://www.thestar.com. my/news/nation/2020/04/04/duo-caught-fishing-say-they-were-onlytrying-feed-their-families-both-get-three-months039-jail.

30. Arumugam T. All calls to Talian Kasih taken seriously, says ministry. New Straits Times [newspaper on the Internet]. 2020 April 4 [Cited 2020 May 2]. Available from: https://www.nst.com.my/news/ nation/2020/04/581313/all-calls-talian-kasih-taken-seriously-saysministry.

31. 5G? Parts of Sarawak don't have Internet at all. The Star [newspaper on the Internet]. 2019 July 4 [Cited 2020 May 2]. Available from: https:// www.thestar. com.my/news/nation/2019/07/04/5g-parts-of-sarawakdont-have-internet-at-all.

32. Razak R. PM says schools to stay closed, home-based learning to be utilised during MCO. Malaymail [newspaper from the Internet]. 2020 April 10 [Cited 2020 May 2]. Available from: https://www.malaymail. com/news/malaysia/2020/04/10/pm-says-schools-to-stay-closed-homebased-learning-to-be-utilised-during-mc/1855459.

33. Rural students without internet access risk being left behind during $\mathrm{MCO}$ The Borneo Post [newspaper on the Internet]. 2020 April 17 [Cited 2020 May 3]. Available from: https://www.theborneopost.com/2020/04/17 rural-students-without-internet-access-risk-being-left-behind-duringmcol.

34. Limited internet access a challenge for online learning, teaching The Malaysian Reserve [newspaper on the Internet]. 2020 April 17 [Cited 2020 May 4]. Available from: https://themalaysianreserve. com/2020/04/17/limited-internet-access-a-challenge-for-onlinelearning-teaching/

35. Koya Z. Covid-19 funerals a very painful affair for loved ones. The Star [newspaper on the Internet]. 2020 March 24 [Cited 2020 May 3]. Available from: https://www.thestar.com.my/news/nation/2020/03/24 covid-19-funerals-a-very-painful-affair-for-loved-ones.

36. Eighteen men jailed, fined for attending funeral during MCO. The Star [newspaper on the Internet]. 2020 April 21 [Cited 2020 May 3]. Available from: https://www.thestar.com.my/news/nation/2020/04/21 eighteen-men-jailed-fined-for-attending-funeral-during-mco.

37. Prime Minister's Office of Malaysia. PRIHATIN Economic Stimulus Package. [Cited 2020 May 2]. Available from: https://www.pmo.gov.my/ prihatin-economic-stimulus-package/.

38. Chung E. Here's a list of financial aid available during the movement control order period. The Rakyat Post [newspaper on the Internet]. 2020 March 23 [Cited 2020 May 2]. Available from: https://www. therakyatpost.com/2020/03/23/financial-aid-malaysia-movementcontrol-order-covid-19/.

39. Timbuong J. Our economy loses RM2.4bil every day MCO is active, says PM. The Star [newspaper on the Internet]. 2020 April 25 [Cited 2020 May 2]. Available from: https://www thestar.com.my/news/ nation/2020/04/25/our-economy-loses-rm24bil-every-day-mco-isactive-says-pm.

40. Razak R. How charity groups are helping the poor and vulnerable get by amid tighter MCO. Malaymail [newspaper on the Internet]. 2020 April 5 [Cited 2020 May 2]. Available from: https://www.malaymail.com/news/ malaysia/2020/04/05/how-charity-groups-are-helping-the-poor-andvulnerable-get-by-amid-tighter/1853628.

41. Timbuong J. Let there be light: M'sians flash their appreciation for frontliners. The Star [newspaper on the Internet]. 2020 April 4 [Cited 2020 May 2]. Available from: https://www.thestar.com.my/ news/nation/2020/04/04/let-there-be-light-m039sians-flash-theirappreciation-for-frontliners.

42. Povera A and Chan D. CMCO to end, replaced with RMCO until Aug 31. New Straits Times [newspaper on the Internet]. 2020 June 7 [Cited 2020 June 7]. Available from: https://www.nst.com.my/news/ nation/2020/06/598700/cmco-end\%C2\%A0replaced-rmco-until-aug31-nsttv.

43. MySejahtera. [Cited 2020 August 16]. Available from: https:// mysejahtera.malaysia.gov.my/intro_en/.

44. Current Situation. Malaysia Ministry of Health [Internet]. 2020 August 15. [Cited 2020 August 16]. Available: http://covid-19.moh.gov.my/ terkini. 